\title{
KEMAMPUAN PEMODELAN MATEMATIKA DALAM REALISTIC MATHEMATICS EDUCATION (RME)
}

\section{Pitriani}

Dosen Pend. Matematika FKIP Univ. Tamansiswa Palembang email : pipit.riany@gmail.com

\begin{abstract}
Mathematical modeling ability: the ability of students in translating a real problem in everyday life sentence into mathematics (mathematical models). Realistic Mathematics Education (RME) is a math learning approach that starts from things that are 'real' for students or contexts easily imagined by students, then represented in the form of formal mathematics through mathematical processes. Learning to use RME to be intensified to remember that this learning can improve students' mathematical modeling ability. By having a good modeling ability so students can complete mathematical problems very well too.
\end{abstract}

Keywords: Realistic Mathematics Education (RME), Mathematical Modeling Ability

\section{Pendahuluan}

Hasil terbaru dari Thrends International Mathematics Science Study (TIMSS) tahun 2011 yang menunjukkan bahwa penguasaan matematika siswa Indonesia kelas VIII SMP berada di peringkat 38 dari 45 negara. Indonesia hanya mampu mengumpulkan 386 poin dari skor rata-rata 500. Hasil ini menjadi tamparan bagi bangsa Indonesia karena poin di tahun 2011 juga menurun, 403 poin pada tahun 1999, 411 poin pada 2003 dan anjlok menjadi 397 poin pada tahun 2007.

Selain itu, penelitian dari Programme for International Student Assessment (PISA) 2009 juga memaparkan hasil yang tidak jauh berbeda. Peringkat Indonesia baru bisa menduduki 10 besar terbawah dari 65 negara dengan rincian Reading (57), Matematika (61) dan Sains (60).

Data ini menunjukkan bahwa secara umum kualitas pendidikan kita kurang memuaskan, hal ini disebabkan siswa kita hanya mampu menyelesaikan soal-soal rutin dan kurang mampu menjawab menyelesaikan masalah aplikasi dalam matematika yang memerlukan penalaran dan keterampilan proses. Dalam pemecahan masalah kontekstual matematika dibutuhkan pemodelan matematika dari persoalan konkrit menuju ke model abstrak. Romizowski (1981) berpendapat bahwa hasil belajar diperoleh dalam bentuk pengetahuan dan keterampilan. 
Pengetahuan dikelompokkan pada 4 kategori yaitu : 1) fakta, 2) konsep, 3) prosedur, dan 4) prinsip. Fakta merupakan pengetahuan terhadap objek nyata, sedangkan konsep merupakan pengetahuan tentang seperangkat objek konkrit atau defenisi. Prosedur merupakan pengetahuan tentang tindakan yang bersifat linier dalam mencapai suatu tujuan. Sedangkan prinsip adalah merupakan pemyataan mengenai hubungan dua konsep atau lebih, hubungan itu bersifat kausalitas, korelasi atau aksiomatis. Keterampilan dikelompokkan ke dalam 4 kategori yaitu : 1) keterampilan kognitif, 2) acting, 3) reacting, dan 4) interaksi. Keterampilan kognitif berkaitan dengan keterampilan seseorang dengan menggunakan pikiran dalam menghadapi sesuatu, seperti pemodelan matematika dalam memecahkan masalah.

Dari penjelasan di atas terlihat bahwa kemampuan pemodelan matematika mempunyai peranan penting. Oleh karena itu harus dicari pembelajaran yang sesuai dengan kemampuan ini. Adapun pembelajaran yang sesuai adalah pembelajaran dengan menggunakan pendekatan Realistic Mathematics Education (RME). Hal ini dikarenakan RME memiliki salah satu karakteristik menggunakan model. Oleh karena itu, penyusun tertarik membahas mengenai kaitan RME dengan kemampuan pemodelan matematika. Tujuan penulis mengkaji hal ini adalah sebagai berikut: a. Untuk mengetahui karakteristik (definisi dan indikator) kemampuan pemodelan matematika.

b. Untuk mengetahui karakteristik Realistic Mathematics Education (RME).

c. Untuk mengetahui kaitan Realistic Mathematics Education (RME) dengan kemampuan pemodelan matematika dan tujuan pembelajaran matematika.

d. Untuk mengetahui bahwa Realistic Mathematics Education (RME) dapat meningkatkan kemampuan pemodelan matematika.

\section{Pembahasan}

\section{Model dan Pemodelan Matematika (Mathematical Modeling)}

Model matematika sebenarnya telah dipelajari siswa sejak duduk di bangku Sekolah Dasar (SD), misalnya ketika mereka menuangkan soal-soal cerita ke dalam perumusan matematika. Bahkan, dalam kehidupan sehari-hari secara tidak sadar siswa telah melakukan pemodelan matematika. Abrams (2001) menyatakan bahwa suatu model matematika merepresentasikan suatu situasi secara simbolik, secara grafik, dan atau secara numerik untuk menguatkan suatu aspek yang pokok dan untuk dipelajari dengan mengenyampingkan hal-hal yang kurang penting. Dengan demikian, model matematika tersebut merupakan terjemahan ide atau gagasan matematika dari suatu masalah nyata yang diungkapkan melalui lambang atau simbol matematika dalam pemecahan masalah. Model 
matematika dibuat sebagai cara dalam penyelesaian masalah yang terjadi dalam kehidupan sehari-hari yang diselesaikan menggunakan matematika.

Selanjutnya Zarlis (2008) menyatakan model adalah representasi dari suatu objek, benda atau ide-ide dalam bentuk lain dari entitasnya. Model berisi informasi-informasi tentang suatu sistem yang dibuat dengan tujuan untuk mempelajari sistem yang sebenarnya. Model dapat berupa tiruan dari suatu benda, sistem atau peristiwa sesungguhnya yang hanya mengandung informasiinformasi yang dipandang penting untuk ditelaah. Lebih lanjut (Zarlis, 2008) mengatakan: model matematika dari suatu masalah adalah rumusan masalah dalam bentuk persamaan atau fungsi matematika. Sedangkan pemodelan matematika dari suatu masalah adalah langkah-langkah yang ditempuh untuk memperoleh dan memanfaatkan persamaan atau fungsi matematika dari suatu masalah.

Menurut Parlaungan (2008) sebuah model matematika memiliki empat komponen model matematika terdiri dari:

1. variabel tak bebas (hasil atau ukuran keefektifan)
2. variabel bebas (alternatif atau unsur mutlak)

3. konstanta atau parameter

4. hubungan antara variabel.

Tidak selamanya setiap model harus memuat unsur keempat komponen ini. Tergantung kepada masalah realnya. Apakah keempat komponen ini muncul sekaligus atau sebagian.

Menurut Setiawan Hem (2008) ada dua jenis model, yaitu: model fisik dan model konseptual. Model fisik adalah realisasi fisik seperti apa adanya namun berukuran kecil. Model konseptual adalah realisasi fisik seperti apa adanya tetapi merupakan pernyataan atau bahasa matematika.

Pemodelan matematika merupakan bidang matematika yang berusaha untuk merepresentasikan dan menjelaskan sistem-sistem fisik atau problem pada dunia real dalam pernyataan matematik, sehingga diperoleh pemahaman dari problem dunia real menjadi lebih tepat (Widowati dan Sutimin, 2007). Representasi matematika yang dihasilkan dari proses ini dikenal kenal dengan model matematika. Menurut Lovitt (1991) pemodelan matematika ditandai oleh dua ciri utama, yaitu (1) pemodelan bermula dan berakhir dengan dunia nyata, pemodelan membentuk suatu siklus. 


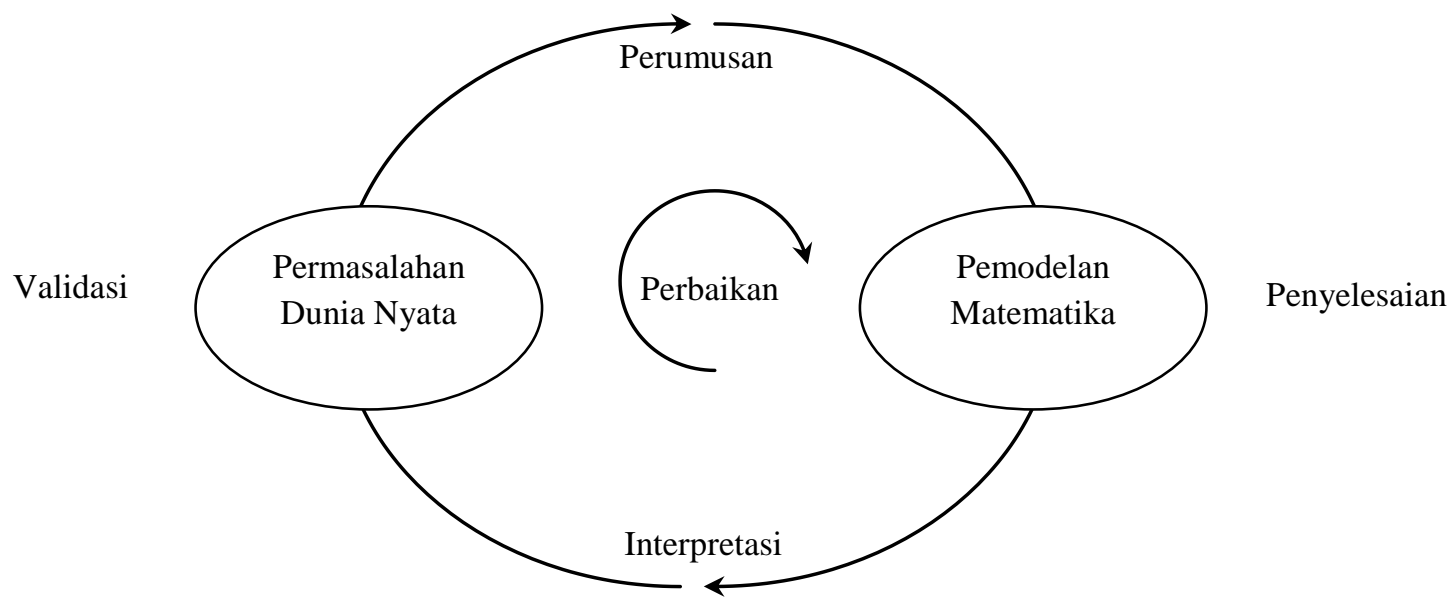

Gambar 1: Pemodelan Matematika Oleh Lovitt

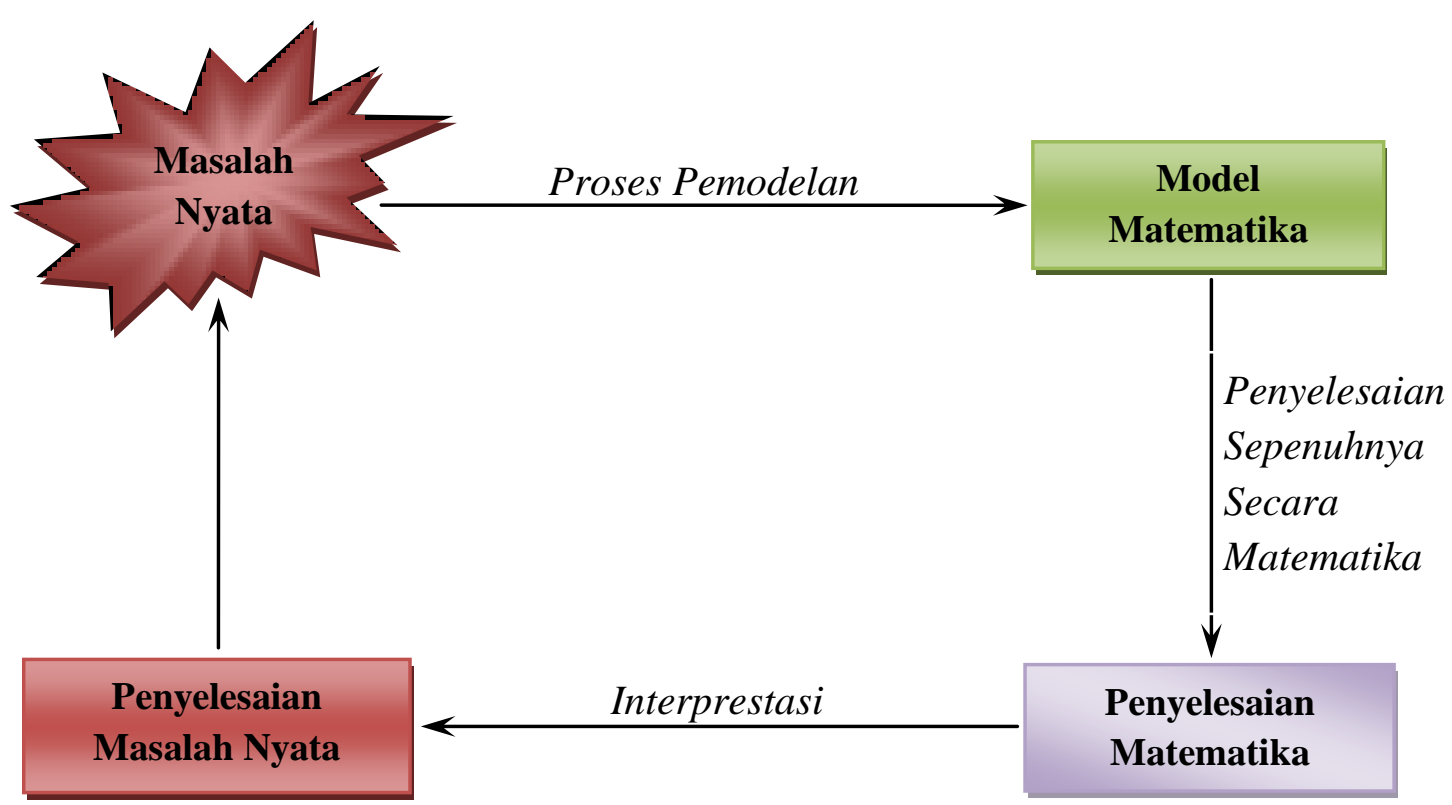

Gambar 2: Alur Penggunaan Pemodelan Matematika

Pemodelan matematika merupakan penerjemahan masalah nyata yang telah diidentifikasikan ke dalam lambang atau bahasa matematika, proses pemodelan dapat diterjemahkan dari fenomena atau masalah dunia real menjadi masalah matematika (Parlaungan, 2008). Infomasi yang diperoleh dari melakukan kajian matematika atas model tersebut dengan menggunakan kaedah-kaedah matematika. Informasi yang diperoleh merupakan bahasa matematika tentang fenomena atau masalah yang dimodelkan tersebut. Secara sederhana, alur dalam menyelesaikan soal matematika dengan menggunakan pemodelan dapat dilihat pada gambar 2 di atas.

Permasalahan nyata yang dikaji itu, mula-mula diterjemahkan ke dalam kalimat matematika (model matematika) dengan memahami 
permasalahan yang ada seperti mengetahui informasi-informasi yang ada di dalam masalah tersebut dan mengetahui apa yang yang yang harus diselesaikan dari masalah yang akan dikaji. Setelah model matematika dibentuk mengikuti kaidah-kaidah matematika, langkah selanjutnya adalah menyelesaikan model tersebut hingga mendapatkan suatu solusi penyelesaian. Penyelesaian model matematika diinterprestasikan sehingga mendapat jawaban dari model matematikanya, jawaban yang diperoleh digunakan untuk menjawab masalah awal.

Dengan menggunakan langkah Polya (1973) dapat memberikan gambaran tentang langkah-langkah penyelesaian soal cerita adalah sebagai berikut.

Langkah 1 : Memahami masalah, meliputi hal-hal berikut

1) Memahami kalimat.

2) Mengubah masalah itu dengan kalimat sendiri.

3) Mengidentifikasi yang diketahui.

4) Mengidentifikasi yang ditanyakan.

Di langkah ini siswa diminta untuk menentukan apa yang diketahui dan apa yang ditanyakan, namun jika siswa tidak mampu maka guru meminta siswa untuk mengubah soal dengan kalimatnya sendiri. Selanjutnya siswa diminta menentukan apa yang diketahui dan apa yang ditanyakan.

\section{Langkah 2 : Menyusun rencana pemecahan}

Setelah memahami maksud dari soal, selanjutnya siswa menyusun rencana penyelesaian soal dengan mempertimbangkan berbagi hal misalnya:

a. Diagram, tabel, gambar atau data lainnya dalam soal.

b. Korelasi antara keterangan yang ada dalam soal dengan unsur yang ditanyakan.

c. Prosedur rutin/rumus-rumus yang dapat digunakan.

d. Kemungkinan cara lain yang dapat digunakan.

\section{Langkah 3 : Melaksanakan rencana pemecahan}

Pada langkah ini siswa diharapkan dapat memilih metode untuk menyelesaikan model matematika.

\section{Langkah 4 : Memeriksa kembali}

Dari hasil yang telah diperoleh, siswa masih dituntut memeriksa kembali dengan cara mensubstitusikan hasil tersebut ke dalam soal semula sehingga dapat diketahui kebenarannya.

\section{Definisi dan Indikator Kemampuan Pemodelan Matematika}

Pembelajaran matematika akan lebih berrnakna dan menarik bagi siswa jika guru menghadirkan masalah-masalah kontekstual dan realistik, yaitu masalah-masalah yang sudah dikenal, dekat dengan kehidupan real sehari-hari siswa. Masalah konstekstual dapat digunakan sebagai titik awal pembelajaran matematika dalam membantu siswa mengembangkan pengertian terhadap konsep matematika yang dipelajari 
dan juga bisa digunakan sebagai sumber aplikasi matematika.

Proses pemodelan bertujuan untuk menyederhanakan suatu permasalahan agar lebih mudah dimengerti oleh siswa. Secara garis besar langkah-langkah membuat model (Zarlis, 2008) adalah sebagai berikut: 1) Pecahkan masalah melalui penyederhanaan. 2) Nyatakan objek dengan pernyataan-pernyataan yang jelas, karena objek akan sangat menentukan model. 3) Cari analoganalog dari sistem yang lain, atau model yang sudah ada untuk mempermudah mengkontruksinya. 4) Tentukan komponen-komponen yang dimasukkan ke dalam model. 5) Tentukan mana variabel, parameter, konstanta, dan hubungan fungsional di antaranya, serta batasan dan fungsifungsi kriterianya. 6) Untuk membuat model matematik, harus dipikirkan pula untuk menyatakan masalah secara numerik jika ingin disimulasi dengan komputer digital. 7) Nyatakan dalam simbol-simbol. 8) Tuliskan persamaan matematiknya. 9) Bila model terlalu rumit sederhanakanlah, sebaliknya bila terlalu sederhana sempurnakanlah.

Menurut Abdurahman (2003) ada tiga tahapan prinsip pengajaran matematika dari konkret menuju ke abstrak yaitu : 1) Tahap konkret: dapat memanipulasi objek nyata (benda langsung) dalam belajar contohnya melihat objek/benda yang berbentuk kubus misalnya bak air, kotak perhiasan, peti, kotak kapur dan lainlain. 2) Tahap representasional yaitu suatu tahapan objek nyata diwakili oleh gambar atau simbol grafis misalnya : 000 = empat kotak kapur berbentuk kubus, tahapan ini disebut pemodelan. 3) Tahap abstrak yaitu tahap menggantikan gambar atau simbol grafis contohnya: $0000(4)+$ $00(3)=7$.

Dari penjelasan di atas maka dapat ditarik kesimpulan bahwa kemampuan pemodelan matematika yaitu kemampuan siswa dalam menerjemahkan suatu permasalahan nyata dalam kehidupan sehari-hari ke dalam kalimat matematika (model matematika). Berdasarkan bahwa pemodelan matematika adalah proses penerjemahan masalah nyata yang telah diidentifikasikan ke dalam lambang atau bahasa matematika dan mengenai alur proses penggunaan pemodelan matematika dalam menyelesaikan soal matematika (lihat kembali gambar 2) serta proses penyelesaian soal cerita yang dikemukan Polya (1973), maka dapat disimpulkan apa saja yang menjadi indikator (kemampuan yang diukur) dalam kemampuan pemodelan matematika, yaitu sebagai berikut:

1. Mengindentifikasi masalah:

- Mengetahui informasi yang didapatkan dari soal.

- Mengetahui konsep yang terkandung dalam soal.

- Mengetahui kata kunci dalam soal.

2. Pembentukan model matematika:

- Dapat memisalkan unsur-unsur yang diketahui ke dalam variabel. 
- Dapat menyusun model matematika sesuai dengan infomasi yang didapatkan dari soal yang telah dipahami.

- Dapat menyederhanakan model matematika.

\section{Realistic Mathematics Education (RME)}

Realistic Mathematics Education (RME) atau pendidikan matematika realistik adalah salah satu pendekatan dalam pembelajaran matematika. RME pertama kali dikenalkan dan dikembangkan di Institute Freudenthal, Belanda. Teori RME ini mengacu pada pandangan Freudenthal mengenai matematika. Dua hal yang harus dikaitkan dalam matematika menurut Freudenthal, yaitu matematika harus dikaitkan dengan hal-hal yang nyata dan matematika sebagai aktivitas manusia. Dalam pembelajaran matematika seharusnya siswa diberi kesempatan untuk menemukan kembali ide atau konsep matematika dengan suatu aktivitas yang dilakukan oleh siswa sendiri. Prinsip penemuan kembali dapat diinspirasi oleh prosedur-prosedur pemecahan informal, sedangkan proses penemuan kembali menggunakan konsep matematisasi (Suharta, 2007).

Terdapat dua tipe matematisasi yang dirumuskan secara eksplisit dalam sebuah konteks pendidikan oleh Treffers (Zulkardi, 1999) yaitu matematisasi horizontal dan matematisasi vertikal. Dalam matematisasi horizontal, siswa mengajukan alat-alat matematik yang dapat membantu untuk menyusun dan menyelesaikan masalah dalam kehidupan sehari-hari, misalnya mengidentifikasi dan menggambarkan matematika spesifik ke dalam konteks yang umum, membuat skema, merumuskan, dan memvisualisasikan suatu masalah dengan cara-cara yang berbeda, menemukan hubungan, menemukan keteraturan atau pola, mentransformasikan masalah dunia nyata ke masalah matematik. Sedangkan matematisasi vertikal adalah proses mereorganisaasi di dalam sistem matematikanya sendiri, misalnya merepresentasi suatu hubungan dalam rumus, membuktikan pola, perbaikan dan penyesuaian model-model, menggunakan modelmodel yang berbeda, merumuskan model matematik, dan generalisasi. 


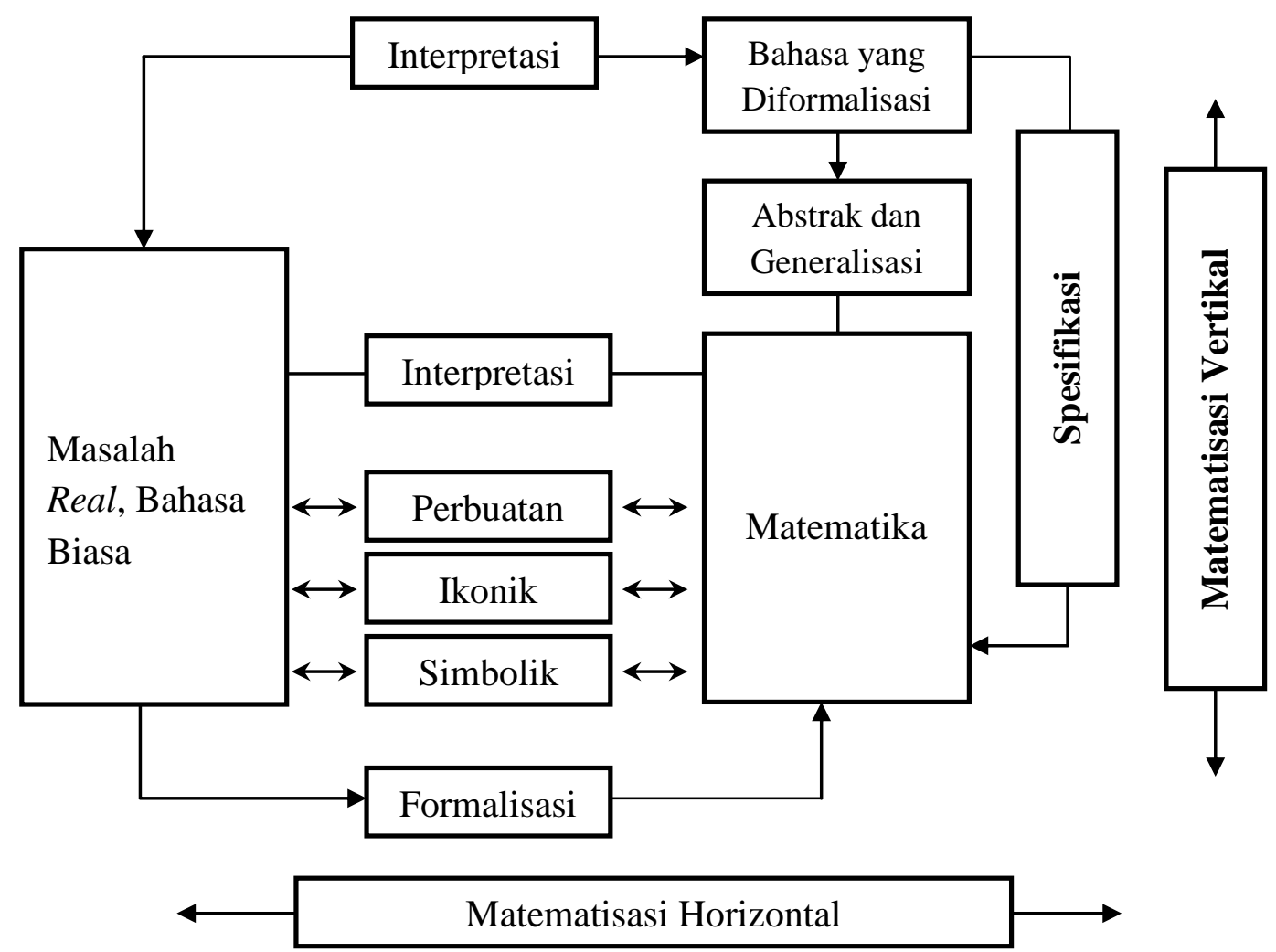

Gambar 3: Deskripsi Matematisasi Horizontal dan Vertikal dalam RME

(Marpaung dalam Setiawati, 2006)

\begin{tabular}{|c|c|}
\hline \multirow[b]{2}{*}{$\begin{array}{l}\text { dari dunia nyata ke dalam dunia } \\
\text { simbol, sedangkan matematisasi } \\
\text { vertikal merupakan proses di dalam } \\
\text { dunia simbol itu sendiri." }\end{array}$} & $\begin{array}{l}\text { 1. Membantu siswa menggunakan } \\
\text { konsep matematika. }\end{array}$ \\
\hline & $\begin{array}{l}\text { 2. Membentuk model dasar } \\
\text { matematika dalam mendukung pola } \\
\text { pikir siswa bermatematika. } \\
\text { 3. Memanfaatkan realitas sebagai } \\
\text { sumber aplikasi matematika. }\end{array}$ \\
\hline $\begin{array}{l}\text { Matematisasi horizontal dan vertikal } \\
\text { saling berkaitan dan berkorelasi. } \\
\text { Dalam RME, masalah reliastik } \\
\text { dijadikan titik tolak dalam } \\
\text { pembelajaran. Masalah realistik akan }\end{array}$ & $\begin{array}{l}\text { 4. Melatih kemampuan siswa, } \\
\text { khususnya dalam menerapkan } \\
\text { matematika pada situasi nyata } \\
\text { (realitas). }\end{array}$ \\
\hline mengarahkan siswa untuk membentuk & Karakteristik Realistic \\
\hline $\begin{array}{l}\text { konsep, menyusun model, menerapkan } \\
\text { konsep yang telah diketahui, dan } \\
\text { menyelesaikan masalah tersebut } \\
\text { berdasarkan kaidah matematika yang } \\
\text { berlaku (Saragih, 2007). Sedangkan } \\
\text { menurut Mulyo (2009), masalah } \\
\text { realistik berfungsi untuk: }\end{array}$ & $\begin{array}{l}\text { Mathematics Education (RME) } \\
\quad \text { Karakteristik dari pembelajaran } \\
\text { matematika berbasis RME (Zulkardi, } \\
\text { 1999; Suharta, 2007; Turmudi 2000), } \\
\text { yaitu sebagai berikut: } \\
\text { a. Menggunakan konteks dunia } \\
\text { nyata }\end{array}$ \\
\hline
\end{tabular}


Dalam RME, pembelajaran diawali dari konteks yang real life ataupun yang dapat dimunculkan dari situasi matematik yang natural bagi siswa. Proses penyarian (inti) dari konsep yang sesuai dari situasi nyata dinyatakan oleh de Lange sebagai matematisasi konseptual. Proses ini akan mendorong siswa untuk menggali situasi, menemukan dan mengidentifikasi konsep-konsep matematika yang relevan, membuat skema dan aturan, serta mengembangkan sebuah "model" yang menghasilkan suatu konsep matematika. Melalui abstraksi dan formalisasi siswa dapat mengembangkan konsep yang lebih kompleks. Kemudian siswa dapat mengaplikasikan konsep-konsep matematika ke dunia nyata sehingga akan memperkuat konsep tersebut.

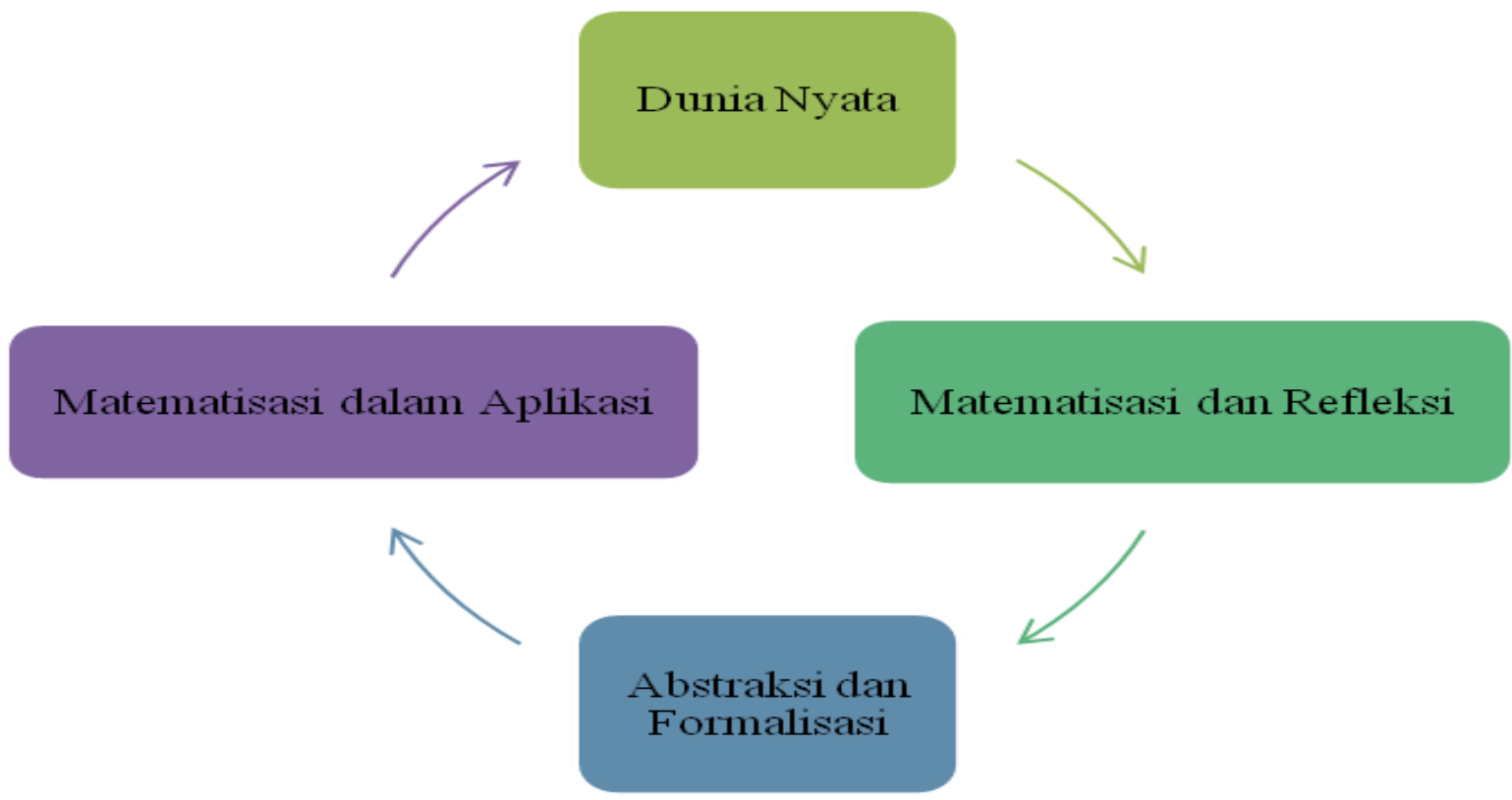

Gambar 4: Konsep Matematisasi

\section{b. Menggunakan model-model}

Istilah model berkaitan dengan model situasi dan model matematika yang dikembangkan oleh siswa itu sendiri (self developed models). Peran self developed models merupakan jembatan bagi siswa dari situasi real ke situasi abstrak atau dari matematika informal ke matematika formal melalui proses matematisasi.

\section{c. Produksi dan konstruksi (kontribusi siswa)}

Siswa harus diberi kesempatan untuk menyumbangkan pemikirannya (memberikan kontribusi), sehingga siswa dapat membuat pembelajaran menjadi konstruktif dan produktif, artinya siswa memproduksi sendiri (student own production) dan mengkonstruksi sendiri (yang mungkin berupa algoritma, atau strategi penyelesaian siswa), sehingga dapat membimbing para siswa dari level matematika informal menuju matematika formal. 


\section{d. Menggunakan interaktif}

Interaksi antar siswa dan antara siswa dengan guru adalah bagian yang sangat penting dalam RME, karena diskusi, kerjasama, dan refleksi sangat penting untuk proses matematisasi. Menurut de Lange dalam Zulkardi (1999), interaksi antar siswa serta interaksi siswa dan guru adalah bagian yang sangat penting dalam RME.

\section{e. Menggunakan keterkaitan (intertwining)}

Dalam RME, pengintegrasian unit-unit matematika sangat penting. Salah satu alasan mengapa matematika sangat sulit diaplikasikan, yaitu bila materi-materi matematika diajarkan secara terpisah, dan mengabaikan keterkaitan antar topik.

Kelima prinsip belajar menurut filosofi realistik di atas inilah yang menjiwai setiap aktivitas pembelajaran matematika dalam RME. Kelima prinsip ini akan menggiring siswa ke dalam pembelajaran yang bermakna

\section{Prinsip Utama Realistic Mathematics Education (RME)}

Tiga prinsip utama dalam RME menurut Gravemeijer (1994) adalah:

a. Guided reinvention and progressive mathematization (penemuan terbimbing dan bermatematika secara progresif)

Prinsip penemuan terbimbing berarti bahwa melalui masalah realistik yang diberikan pada awal pembelajaran siswa diberi kesempatan untuk menemukan konsep, prinsip, sifat-sifat dan rumus-rumus matematika. Dalam proses menyelesaikan masalah realistik, siswa diberi arahan dan bimbingan secukupnya oleh guru.

Menurut Traffers (Saragih, 2007), bermatematika secara progresif dapat dibagi atas dua komponen yaitu bermatematika secara secara horizontal dan vertikal. Contoh matematisasi horizontal adalah pengidentifikasian, perumusan dan pemvisualisasian masalah dalam cara yang berbeda, dan pentransformasian masalah dunia nyata ke masalah matematik. Contoh matematisasi vertikal adalah representasi hubunganhubungan dalam rumus, perbaikan dan penyesuaian model matematik, penggunaan model-model yang berbeda, dan penggeneralisasian (Penhuzen dalam Zainurie, 2007).

$$
\text { Pada proses matematisasi }
$$
masalah-masalah realistik, siswa bermatematisasi horizontal ketika siswa mengidentifikasi bahwa soalsoal realistik harus ditransfer ke dalam soal bentuk matematika untuk lebih dipahami melalui penskemaan, perumusan, dan pemvisualisasian. Sedangkan dalam bermatematisasi vertikal siswa menyelesaikan bentuk matematika dari masalah realistik menggunakan konsep, operasi, dan prosedur matematika yang berlaku (Saragih, 2007).

\section{b. Didactical phenomenology}

Prinsip

didactical phenomenology menekankan pada pentingnya masalah realistik untuk memperkenalkan topik-topik matematika pada siswa. Dalam 
masalah realistik yang diberikan, harus dipertimbangkan kesesuaian antara aplikasi konteks dengan topik-topik matematika yang diajarkan dan kesesuaian dampak dalam proses penemuan kembali konsep, prinsip, rumus, prosedur dan model matematika dari masalah realistik tersebut.

\section{c. Self-developed} model (pengembangan model mandiri)

Menurut prinsip ini, model yang dibangun berfungsi untuk menjembatani antara pengetahuan matematika informal dan matematika formal siswa. Siswa akan membentuk model matematika untuk menyelesaikan masalah realistik. Mulai dari model dalam bentuk informal kemudian model dalam bentuk formal sampai akhirnya mendapatkan penyelesaian masalah.

Ada empat tahap pemodelan dalam desain pembelajaran RME, sebagai berikut:

a) Tahap situasi, di mana domainspesifik, pengetahuan situasi dan strategis digunakan dalam situasi yang kontekstual.

b) Tahap referensi atau "model of", di mana model dan strategi berkaitan dengan situasi yang digambarkan dalam masalah.

c) Tahap perumuman atau "model for", di mana fokus matematis pada strategi mendominasi konteksnya.

d) Tahap matematika formal, pada tahap ini penuh dengan prosedurprosedur konvensional dan notasinotasi.

\section{Kaitan RME dengan \\ Kemampuan Pemodelan \\ Matematika}

Kemampuan pemodelan matematika adalah kemampuan yang dimiliki siswa untuk menyajikan masalah nyata (informal) menjadi bentuk abstrak (formal) dalam bentuk tampilan gambar, grafis, prosedur kerja yang teratur dan sistematis, serta mengandung pemikiran bersifat uraian atau penjelasan untuk menyelesaikan permasalahan matematika. Pemodelan berfungsi untuk menjembatani pengetahuan matematika nonformal dan matematika formal dari siswa. Siswa mengembangkan model tersebut dengan menggunakan model matematika (formal dan nonformal) yang telah diketahui dengan menyelesaikan soal kontekstual dari situasi real yang sudah dikenal siswa sehingga ditemukan model dari (model of) dalam bentuk informal kemudian diikuti dengan menemukan model dari (model for) dalam bentuk formal sehingga siswa mendapatkan kemudahan dalam menyelesaikan masalah yang kontekstual.

Mata pelajaran matematika di Indonesia sesuai ketetapan pemerintah melalui BSNP (Permendiknas No. 22 Tahun 2006), bertujuan agar peserta didik memiliki kemampuan sebagai berikut:

1. memahami konsep matematika, menjelaskan keterkaitan antarkonsep dan mengaplikasikan konsep atau algoritma, secara luwes, akurat, efisien, dan tepat, dalam pemecahan masalah; 
2. menggunakan penalaran pada pola dan sifat, melakukan manipulasi matematika dalam membuat generalisasi, menyusun bukti, atau menjelaskan gagasan dan pernyataan matematika;

3. memecahkan masalah yang meliputi kemampuan memahami masalah, merancang model matematika, menyelesaikan model dan menafsirkan solusi yang diperoleh;

4. mengomunikasikan gagasan dengan simbol, tabel, diagram, atau media lain untuk memperjelas keadaan atau masalah;

5. memiliki sikap menghargai kegunaan matematika dalam kehidupan, yaitu memiliki rasa ingin tahu, perhatian, dan minat dalam mempelajari matematika, serta sikap ulet dan percaya diri dalam pemecahan masalah.

Maka jelaslah bahwa kemampuan pemodelan matematika sangat penting untuk dimiliki oleh setiap siswa sebab kemampuan ini masuk ke dalam tujuan pelajaran matematika di Indonesia.

Dalam RME, pemodelan merupakan salah satu karakteristik yang mempunyai peranan penting dalam membantu siswa untuk menyelesaikan permasalahan matematika. Bagi siswa yang memiliki kemampuan kognitif tinggi model konkret mungkin tidak banyak membantu malah mungkin membosankan dan bahkan dengan model abstrak atau tanpa pemodelan dimungkinkan siswa dapat menyelesaikan permasalahan. Tetapi bagi siswa yang berkemampuan sedang dan rendah model konkret sangat bermanfaat sebagai alat bantu dalam menjabarkan dan memvisualisasikan masalah konteks dunia nyata dalam matematika. Dari uraian di atas dapat diduga bahwa

RME dapat meningkatkan kemampuan pemodelan matematika siswa.

Berikut bagan kaitan antara RME dengan kemampuan pemodelan matematika dan tujuan pembelajaran matematika di sekolah. RME adalah salah satu pendekatan yang sesuai untuk meningkatkan kemampuan pemodelan matematika serta tujuan pembelajaran matematika. 


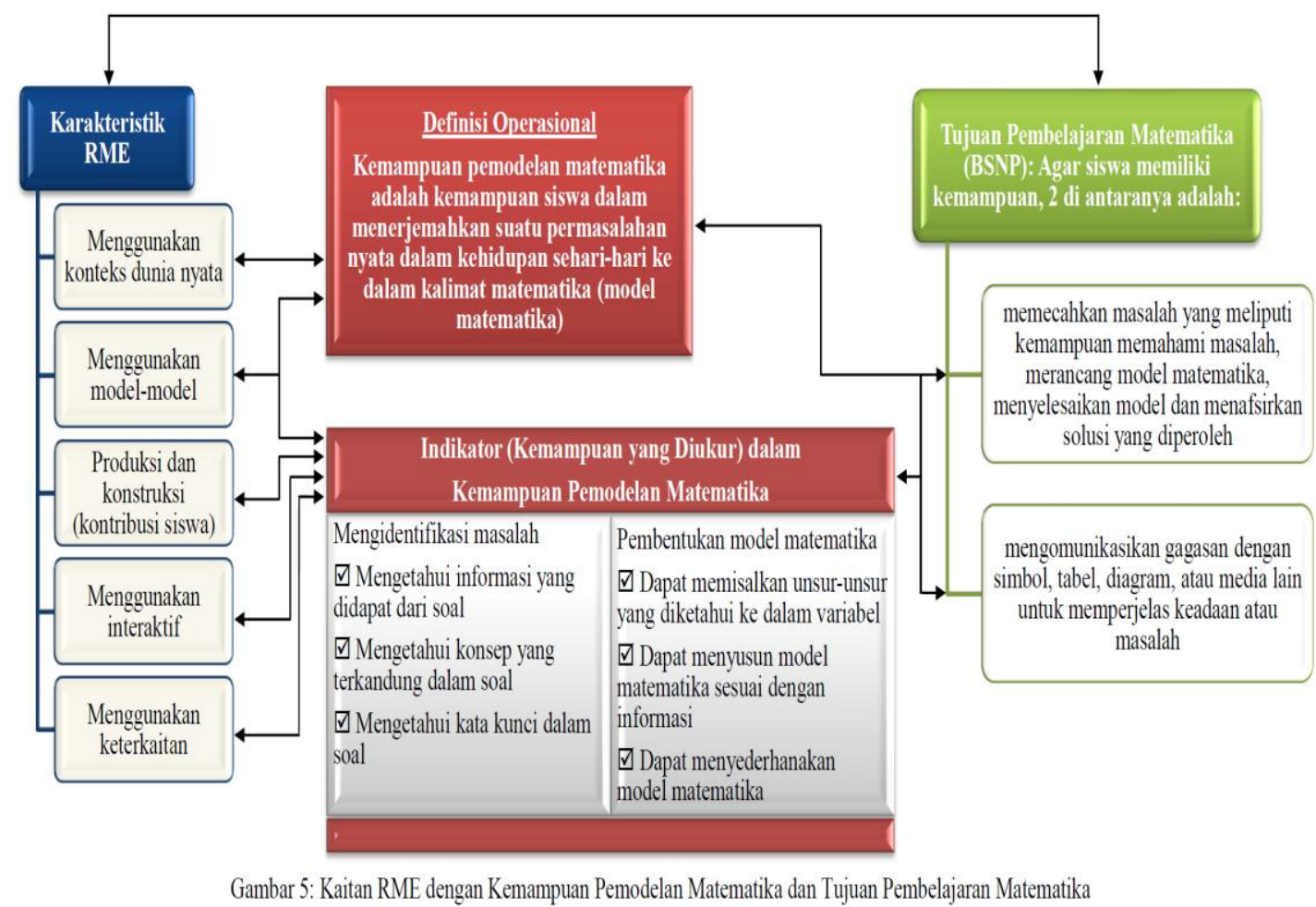

Bagan ini menunjukkan bahwa RME "matching" dan dapat meningkatkan kemampuan pemodelan matematika sesuai tuntutan tujuan pembelajaran matematika di sekolah sebagaimana diamanatkan oleh Permediknas №. 22 Tahum 2006

\section{Penelitian yang Relevan}

Untuk memperkuat argumen bahwa RME dapat meningkatkan kemampuan pemodelan matematika maka penyusun akan menunjukkan beberapa penelitian yang relevan.

Rahayu (2005) menjelaskan bahwa pembelajaran matematika dengan PMRI, perolehan nilai siswa pada ulangan umum bersama lebih tinggi dari perolehan nilai matematika siswa yang tidak menggunakan PMRI. Lebih lanjut Rahayu menegaskan bahwa pembelajaran matematika dengan PMRI ternyata benar-benar membawa pengaruh besar dalam pengembangan pemahaman matematika dalam diri anak pada umumya. Pemahaman ini dapat ditunjukkan ketika siswa mengerjakan suatu soal, dengan menggunakan model sendiri yang dapat berbeda dengan temantemannya. Siswa selalu berpikir tentang kaitan suatu soal dengan soal yang sudah pernah siswa selesaikan, atau antara suatu meteri baru dengan materi lama yang pernah dipelajari. Dengan demikian, siswa yang sudah dapat mengerjakan suatu soal sebelumnya, besar kemungkinannya dapat mengerjakan soal yang sedang dihadapinya.

Turmudi dan Dasari (2000), serta Sabandar dan Turmudi (2001) mencatat bahwa sekurang-kurangnya pendekatan realistik telah mengubah image siswa tentang matematika. Umumnya para siswa di beberapa SMP di Bandung merasa senang dan bersikap positif terhadap pembelajaran 
matematika menggunakan pendekatan matematika realistik. Dalam penelitian tersebut beberapa siswa berkomentar: "Cara belajar seperti ini cukup bagus, enak ada diskusinya jadi yang pintar bisa bagi-bagi dan ingin mencoba soal yang lain supaya bisa." Ada juga yang berkomentar: "Dalam mengerjakan soal sekalipun modelnya berbeda-beda akan tetapi hasil akhirnya sama. Dengan pendekatan matematika realistik, matematika menjadi terasa lebih mudah dipahami, tidak membosankan, mengasyikkan, lebih jelas dan membuat soal lebih mudah dikerjakan. "Lebih lanjut Turmudi (2001) dalam penelitiannya tentang "Implementasi Awal Pembelajaran Matematika dengan Pendekatan Matematika Realistik di SLTP Negeri 2 Bandung" mengatakan bahwa dengan pendekatan matematika realistik siswa merasa cukup terbantu dalam menyelesaikan soal, karena siswa dapat membayangkan soal dengan mudah. Hal ini jarang ditemukan bahwa siswa dapat membayangkan soal yang diberikan.

Atkitson (dalam Panjaitan 2006) mengemukakan bahwa bagi pebelajar yang mengalami kesulitan dalam menyelesaikan soal-soal matematika, harus dibantu dengan memberikan soal-soal yang lebih sederhana, agar pebelajar dapat memahami cara-cara penyelesaian sesuai dengan langkahlangkah yang dibutuhkan. Lebih lanjut Bell (dalam Panjaitan 2006) mengemukakan bahwa dalam belajar matematika, siswa harus mampu memahami soal-soal yang akan dikerjakan, mampu memahami apa yang ditanya, memahami cara melakukan operasi untuk mencapai tujuan itu, serta mampu melakukan evaluasi terhadap yang dilakukan agar dapat memikirkan cara atau prosedur penyelesaian yang mungkin. Dengan demikian untuk menyelesaikan soalsoal matematika dibutuhkan pemodelan matematika agar pemecahan masalah kontekstual lebih mudah dan cepat.

Ruseffendi

mengemukakan bahwa matematika modern lebih baik untuk anak berkemampuan tinggi (pandai) tetapi lebih jelek untuk anak lemah, sedang back to basic lebih baik untuk anak kemampuan rendah (lemah) dan lebih jelek untuk anak berkemampuan tinggi (pandai). Dalam pendekatan matematika realistik (PMR) di mana pemodelan merupakan salah satu karakteristiknya memainkan peranan yang sangat penting dalam membantu siswa menyelesaikan permasalahan matematika. Bagi siswa yang pandai (kemampuan tinggi) model konkrit mungkin tidak banyak membantu malah mungkin membosankan dan bahkan dengan model abstrak atau tanpa pemodelan dimungkinkan siswa dapat menyelesaikan permasalahan. Sebaliknya bagi siswa kemampuan sedang dan rendah bagi mereka model konkrit sangat bermanfaat sebagai alat bantu dalam menjabarkan dan memvisualisasikan masalah kontekstual dalam pemecahan masalah matematika.

Kemudian menurut Nainggolan (2009) terdapat perbedaan rata-rata kemampuan pemodelan matematika 
siswa yang dibelajarkan melalui Pendekatan Matematika Realistik (PMR) dengan pendekatan ekspositori. Pada kelompok motivasi tinggi, pendekatan ekspositori memberikan skor rata-rata kemampuan pemodelan matematika yang lebih tinggi dari pada PMR. Sedangkan pada siswa kelompok motivasi rendah pendekatan matematika realistik memberikan skor rata-rata kemampuan pemodelan matematika siswa yang lebih tinggi dari pada menggunakan pendekatan ekspositori. Dengan demikian pendekatan pembelajaran matematika realistik lebih efektif diterapkan dalam pembelajaran matematika untuk meningkatkan kemampuan pemodelan matematika siswa pada siswa yang memiliki motivasi belajar rendah. Dengan demikian dapat disimpulkan bahwa RME dapat membantu meningkatkan kemampuan pemodelan matematika.

\section{Penutup}

Berdasarkan kajian terhadap berbagai sumber, baik kajian teori dari buku maupun penelitian yang relevan maka dapat ditarik kesimpulan bahwa RME adalah pembelajaran yang sesuai untuk meningkatkan kemampuan pemodelan matematika siswa. Pembelajaran dengan menggunakan RME harus digiatkan, mengingat bahwa pembelajaran ini dapat meningkatkan kemampuan pemodelan matematika siswa. Dengan memiliki kemampuan pemodelan yang baik maka siswa dapat menyelesaikan permasalahan matematis dengan baik juga.

\section{Daftar Pustaka}

Abdurahman, Muliono. 2003. Pendidikan Bagi Anak Berkesulitan Belajar. Jakarta: Depdikbub Rineka Cipta.

Abrams, J. P. 2001. Mathematical Modeling: Teaching the Openended Application of Mathematics. [Online]. Tersedia: http//www.meaningfulmath.org/ modelingcycle.pdf $[29$ April 2013].

BSNP. 2006. Permendiknas RI No. 22 Tahun 2006 tentang Standar Isi untuk Satuan Pendidikan Dasar dan Menengah. Jakarta.

Gravemeijer. 1994. Developing Realistics Mathematics Education. Freudenthal Institute Utrecht.

http://edukasi.kompasiana.com/2011/0 1/30/indonesia-peringkat-10besar-terbawah-dari-65-negarapeserta-pisa/

http://timssandpirls.bc.edu/timss2011/i nternational-resultsmathematics.html

Lovitt. 1991. Math Problems Solving and Modelling. Cengage SouthWestern: UM International Math Ser.

Mulyo, K. 2009. Kajian Kesetarapan antara Pendekatan Kontekstual dengan Realistik Mathematic Education. [Online]. Tersedia: http://karyailmiahbatang.blogspot.com/2009/05/ka 
jiankesetarapan-antara-

pendekatan.html [April 2009]

Panjaitan Binsar. 2006. Karakteristik Pebelajar dan Kontribusinya terhadap Hasil Belajar. Medan: Penerbit Poda.

Parlaungan. 2008. Pemodelan Matematika untuk Peningkatan Bermatematika Siswa Sekolah Menengah Atas (SMA). Sekolah Pascasarjana Universitas Sumatera Utara: Tesis (Tidak diterbitkan).

Polya. 1973. How To Solve It. Princeton New Jersey: Princeton University Press.

Rahayu. 2005. Pembelajaran Matematika dengan Pendekatan PMRI Memang Beda: Buletin PMR1JVI/F'eb/2005.

http://www.pmri.or.id/main.php didownload 29 April 2013.

Romizwoski, A. J. 1981. Designing Instructional System. London: Kongen Page Ltd.

Ruseffendi, E. T. 1991. Pengantar Kepada Membantu Guru Mengembangkan

Kompetensinya dalam Pengajaran Matematika untuk Meningkatkan CBSA. Bandung: Tarsito.

Saragih, $\quad$ Sahat. 2007. Mengembangkan Kemampuan Berpikir Logis dan Komunikasi Matematika Siswa SMP melalui Pendekatan Matematika Realistik. Sekolah Pascasarjana
Universitas

Pendidikan

Bandung:

Disertasi

(Tidak

diterbitkan).

Setiawan, Hem. 2008. Matematika Terapan dan Pemodelan. Surabaya: Jurusan Teknik Kimia FTI-ITS

http://www.its.ac.id/oersonal/ma terial.php?id=heru-che didownload 28 April 2013.

Suharta, I. G. P. 2005. Matematika Realistik: Apa dan Bagaimana? [Online]:

Tersedia: http://www.duniaguru.com/ [18 April 2013].

Turmudi. 2000. Peningkatan Kemampuan Pemahaman Konsep Matematika bagi Siswa SLTP melalui Pendekatan Realistik. Laporan Penelitian Due-Like (Tidak diterbitkan).

Turmudi. 2001. Implementasi Awal Pembelajaran Matematika dengan Pendekatan Realistik di Sekolah Lanjutan Tingkat Pertama Negeri 2 Bandung. Bandung: Laporan Penelitian Mandiri, FPMIPA-UPI (Tidak diterbitkan).

Zainurie. 2007. Pembelajaran Matematika Realistik (RME). From (online):http://zainurie.wordpres s.com/2007/04/13/pembelajaranmatematika-realistik-rme/. April 2013].

Zarlis, Muhammad. 2008. Prinsip Pemodelan Matematika. Medan: 
Universitas Sumatera Utara.

Tidak diterbitkan.

Zulkardi. 1999. How to Design

Mathematics Lessons Based on

the Realistic Approach?

[Online]. Tersedia:

http://www.geocities.com/ratuil

ma/rme.html [29 April 2013]. 
